\section{Çevre ve İş Sağlığı ve Güvenliği Yönetim Sistemlerine Yatırım Yapan Firmalarda Çalışan Memnuniyeti Tutumlarının İncelenmesi}

\author{
Mustafa Cahid ÜNĞAN \\ Sakarya Üniversitesi, İşletme Fakültesi, İşletme Bölümü \\ ungan@sakarya.edu.tr \\ Metin BAYRAM \\ Sakarya Üniversitesi, Arifiye MYO, Mülkiyeti Koruma Bölümü \\ metinbayram@sakarya.edu.tr
}

\section{Özet}

Bu çalışmada ISO 14001 çevre yönetim sistemi (ÇYS) ve OHSAS 18001 iş sağlığ1 ve güvenliği yönetim sistemi (ISGGS) belgelerine sahip olan firmalarda önleme maliyetlerindeki yönelimlerine bağlı olarak çalışan memnuniyeti algılarının incelenmesi amaçlanmıştır. Bu amaçla Türkiye'de faaliyet gösteren ISO 14001 ve OHSAS 18001 belgeli 148 firmadan veri toplanmıştır. Firmaların kazaları en aza indirmek için yaptıkları önleme maliyetleri verileri tanımlayıcı istatistik yöntemiyle ve çalışan memnuniyeti algıları ise Tek-Örnek $t$-Testi $(t=3.25)$ yöntemiyle analiz edilmiştir. Bulgular, katılımcı firmaların kazaları önleme hususunda İSG yönetim sistemi ve yasal şartları tam sağlayacak kadar harcama yaptıklarını ve buna bağlı olarak çalışan memnuniyeti algısını ölçmek üzere hazırlanan beş sorunun dördünde olumlu tutuma sahip olduklarını ortaya koymuştur. Katılımcı firmaların karakteristik özellikleri dikkate alındığında ise büyük ölçekli (çalışan sayısı 250'den fazla) ve beş yıldan fazla süredir bu yönetim sistemlerinin uyguladığını belirten firmaların diğerlerine nazaran açık ara çevre ve iş sağlı̆̆ ve güvenliğine yatırım yaptıkları ve çalışan memnuniyetinde de daha fazla olumlu sonuç aldıkları bulunmuştur. Bu çalışma sonucunda, ÇYS ve İSGYS uygulamalarına yatırım yapan firmalarda firma performansına olumlu etkisi olan çalışan memnuniyetinde iyileşme sağlandığına dair yeterli kanıtlar sağlanmıştır.

Anahtar Kelimeler: Çalışan memnuniyeti, önleme maliyetleri, çevre yönetim sistemi, İSG yönetim sistemi

The attitudes of firms investing in environmental and occupational
Çevre ve İş Sağlığı ve Güvenliği Yönetim Sistemlerine Yatırım Yapan Firmalarda Çalışan Memnuniyeti Tutumlarının İncelenmesi 
Çevre ve İş Sağlığı ve

\section{Güvenliği}

Yönetim

Sistemlerine

Yatırım Yapan

Firmalarda

Çalışan

Memnuniyeti

Tutumlarının İncelenmesi

54 health and safety management systems on employee satisfaction and accident prevention

\section{Abstract}

The purpose of this study is to analyze the perceptions both ISO 14001 and OHSAS 18001 certified firms on employee satisfaction and accident prevention depending on their investments. For this purpose, data was collected from 148 firms operating in Turkey. Descriptive statistics was used to analyze cost data to prevent any accidents from happening. On the other hand, one sample t-test $(t=3,25)$ was used to measure the perceptions of firms towards employee satisfaction. Findings show that participating firms invest the least amount to meet the legal requirements and as a consequence, have positive perceptions of four out of five variables of customer satisfaction scale. Also, we found that the firms, which have more than 250 employees and using the management systems more than five years, invested more on prevention costs for occupational health and safety and, also have a more positive attitude for employee satisfaction than the others. The results provide enough evidence regarding the impact of investing on OHSAS 18001 and ISO 14001 that this investment leads to an improvement in customer satisfaction which has a direct impact on productivity and profitability.

Key words: Employee satisfaction, prevention costs, ISO 14001, OHSAS 18001.

\section{Giriş}

Yönetim sistemleri denildiğinde ilk akla gelenler ISO 9001 kalite yönetim sistemi (KYS), ISO 14001 ÇYS ve OHSAS 18001 İSGYS olup, her üçü birden şirketlerin firma performanslarını olumlu yönde etkileyen uygulamalardır. Çevre ve iş sağlığı ve güvenliği (İSG) alanında beklenti; kuruluşların ürün veya hizmeti üretirken çevreye saygılı olmaları, İSG ile ilgili önlemleri almaları ve sosyal sorumluluklarını yerine getirmeleri yönündedir. Bundan dolayı kalite, çevre ve İSG sistemlerinin birbirine entegre olması zorunluluğu getirilmiştir. Planla-Uygula-Kontrol Et-Önle (PUKÖ) döngüsü esas alınarak tasarlanan ISO 9001 KYS, ISO 14001 ÇYS ve OHSAS 18001 İSGS ve birbirleriyle uyumlu olup, birbirlerine kolayca entegre edilebilmekte ve eş zamanlı olarak uygulanabilmektedir. Bu yönetim sistemlerini uygulayan firmalar müşterilerine daha fazla değer sağlayarak ve proseslerinde verimlilik artışı sağlayarak firma performansını iyileştirme üzerine odaklanmaktadır. Firma performansının iyileştirilmesinde en önemli faktörlerden birisi de şüphe yok ki çalışan memnuniyetinin sağlanmasıdır. 
Örgütsel performans üzerindeki önemli etkisinden dolayı, çalışan memnuniyeti literatürde geniş çapta incelenmiştir (Huang ve Sharyn, 2014). Kuruluşlar iş kazalarının önlenmesi ve azaltılması ve iş güvenliği performansının iyileştirilmesi için bir İSGYS yaklaşımına yatırım yaparken, çalışanlarının zihinleri ve kalplerini kazanma konusuna da dikkat etmelidirler. Bunun için de çalışanların katılımını artırmak ve teşvik etmek üzere tasarlanmış insan performansı esaslı iş güvenliği yönetim sistemleri kullanılmalıdır (Wachter ve Yorio, 2014).

ÇYS'nin çalışanların moral, motivasyon ve memnuniyetini artırdığına dair bazı çalışmalar olmakla birlikte, ÇYS'nin çalışanlar üzerinde etkilerini açıklayan ampirik (deneysel) kanıtlar bulunmamaktadır (Chan ve Hawkins, 2010). Chan ve Hawkins'in (2010) literatürdeki bu eksikliği gidermek için yaptığı çalışmada ÇYS'nin kuruluşlara olan faydalarından birisinin de artan iş memnuniyeti olduğu ampirik olarak ortaya koyulmuştur. Ayrıca, literatürde çevre yönetim sistemi ile çalışan memnuniyeti arasındaki ilişkiyi inceleyen birkaç çalışma daha bulunmaktadır (Quazi ve ark., 2001; Kaur, 2011; Tarí ve ark., 2012). Quazi ve ark. (2001) ISO 14000 standardına sahip olunması konusunda kuruluşları motive eden faktörlerden birinin çalışanların refahı (sağlıklı ve iyi olmaları) olduğunu ampirik olarak ortaya koymuştur. Kaur (2011) tarafından 14001 belgeli firmalar üzerinde gerçekleştirilen çalışmanın bulguları standardın maddelerinden yönetimin taahhüdü ve yetkilendirmesinin çalışanların tutumunu olumlu yönde etkilediğini ortaya koymakla birlikte ve bu çalışmada geri besleme, gözden geçirme ve iş memnuniyeti arasında da anlamlı pozitif ilişkiler tespit edilmiştir. Tarí ve ark. (2012) tarafından yapılan saha çalışmasında ise ISO 9001 ve ISO 14001 standartlarının uygulanmasından elde edilen faydaların benzerlikleri ve farklılıkları ortaya konulmuş ve ISO 14001 standardının çalışanlar yönünden faydaları; moral ve motivasyon artışı, beceri ve hünerlerinin zenginleşmesi, çalışanlar arasında şirket imajının iyileşmesi ve yönetim ve çalışanlar arasında daha iyi diyalogların sağlanması olarak belirtilmiştir.

İSG için önleme harcaması yapılmasının başka bir deyişle İSG yönetimine yatırım yapılmasının çalışan memnuniyeti üzerinde olumlu etkisi olduğu farklı yazarlar tarafından ortaya konulmuştur (Torp ve Moen, 2006; Grawitch ve ark.,2007; Gupta ve Upadhyay, 2012; Omusulah (2013). Torp ve Moen (2006) tarafından gerçekleştirilen 1 yıllık prospektif çalışmasında, Norveç İç Kontrol Yasasına uygun olarak firmalarda ISG yönetiminin uygulanması ve iyileştirilmesi ile işçi memnuniyeti arasında olumlu bir ilişki olduğu ortaya konulmuştur. Grawitch ve ark. (2007), Gupta ve Upadhyay (2012) ve Omusulah (2013) İSG önlemlerinin alınmasının veya
Çevre ve İş̧ Sağlığı ve Güvenliği Yönetim Sistemlerine Yatırım Yapan Firmalarda Çalışan Memnuniyeti Tutumlarının İncelenmesi 
Çevre ve İş Sağlığı ve Güvenliği Yönetim Sistemlerine Yatırım Yapan Firmalarda Çalışan Memnuniyeti Tutumlarının İncelenmesi 56 sağlıklı işyeri uygulamalarının çalışan memnuniyeti üzerinde ciddi etkisi olduğunu ortaya koymuşlardır. Gervais ve ark.(2009) ise sağlık ve güvenlik alanına yapılan yatırımlar sonucu elde edilecek dolaylı faydaları azaltılmış devamsızlık, azaltılmış işgücü devri, iyileşen kurumsal imaj, ihale almayı kolaylaştırma ve iyileştirilmiş iş tatmini/moral olarak sayılabileceğini belirtmiştir. Türkiye'de de bazı yazarlar tarafından yapılan ampirik çalışmalar, İSG önlemlerinin alınması ile çalışan memnuniyeti arasındaki ilişkiyi ortaya koymaktadır (Tanrıverdi, 2006; Kanoğlu, 2007; Çubukel, 2008; Yıldız, 2013). Kanoğlu (2007) tarafından yapılan ampirik çalışmada da ücret dişı faktörlerden olan iş güvenliğinin ücrete nazaran iş tatmini üzerinde etkisinin daha yüksek olduğu ortaya konulmuştur. Ayrıca, bazı yazarlar tarafından gerçekleştirilen ampirik çalışmalar işyeri fiziksel ortamının çalışan memnuniyeti ve performansı üzerindeki etkilerini ortaya koymaktadır (Öğer, 2009; Gedik, 2010; Pelit ve Öztürk, 2010).

Araştırmacılara göre, gerek büyük ölçekli firmalarda iş kazasının en az düzeyde olduğu bulgusu gerek yasal yükümlülüklerden gerekse iş güvenliği kültürünün büyük ölçekli işyerlerinde daha iyi yerleşmesinden hareketle, iş güvenliği yönetim sistemlerinin uygulanmasının iş kazalarını azalttığını göstermektedir (Aytaç, 2011). Demirbilek ve Pazarlığlu (2006) 1980-2005 yılları arasında Türkiye'de yaşanan iş kazalarını incelemişler ve çalışan sayısı 500'ün üzerinde olan büyük ölçekli firmalarda iş kazasının en az düzeyde olduğunu tespit etmişlerdir. Yorio ve Watcher (2014) yaptıkları bir çalışmada kendileri tarafından belirlenen bireysel uygulamalarının her birinin objektif kuruluş düzeyi iş güvenliği performansını büyük ölçüde tahmin ettiğini buldular. Ayrıca, Yorio ve Watcher (2014) çalışmalarında iş kazaları üzerinde bu bireysel uygulamaların etkilerinin ana endüstriyel sektörlerde değişmediğini, ancak kuruluş büyüklüğüne bağlı olarak değiştiğini ortaya koydular.

Bazı yazarlar İSG sistemlerinin tam olgunluk seviyesine ulaşmasını arzu eden firmaların, ISSG sistemlerine daha fazla kaynak ayırmalarının gerektiğini belirtmişlerdir (Rikhardsson ve Impgaard, 2004; Battaglia ve ark., 2014). Hiç kuşkusuz kazaları önlemek amacıyla kurulacak yönetim sistemleri yapılacak her türlü iş güvenliği harcaması ve yatırımı, iş kazası meydana geldikten sonraki dolaysız, dolaylı ve dışsal maliyetlerden çok daha ucuz olacaktır (Ofluoğlu ve Sarıkaya, 2005).

Literatürde hem ÇYS ile çalışan memnuniyeti hem de İSGYS ile çalışan memnuniyeti arasındaki ilişkiler ampirik olarak ayrı ayrı olmak üzere ortaya konulmaktadır. Ancak, her iki yönetim sistemini birden uygulayan firmaların çalışan memnuniyeti sonuçları ile ilgili literatür bilgisine, bilgimizle sınırlı olmak kaydıyla, rastlanılamamıştır. Diğer yandan, bu 
araştırmanın bulguları Türkiye'de yönetim sistemlerini önemseyerek kaynak ayıran firmaların genellikle OHSAS 18001 hem de ISO 14001 belgelerinin her ikisine birden sahip olduklarını ortaya koymaktadır. Bu itibarla, bu çalışmanın literatürdeki bu boşluğu doldurulacağı düşünülmektedir.

Bu çalışmada Türkiye'deki değişik sektörlerden farklı büyüklükte ve tehlike sınıfında yer alan ve hem OHSAS 18001 hem de ISO 14001 belgelerine sahip firmalardan çekilen bir örneklem üzerinde firmaların kazaları önlemek amacıyla yaptıkları harcamalara bağlı olarak çalışan memnuniyeti algılarını incelemek amaçlanmaktır.

\section{Yöntem}

Bu çalışma Tablo 1.'de verilen adımlar izlenerek gerçekleştirilmiştir.

Tablo 1. Araştırma yöntemi olarak izlenen adımlar

\begin{tabular}{|c|c|}
\hline Adım & Faaliyet \\
\hline 1 & Araştırma amacına yönelik olarak bir anket formu tasarlanmıştır. \\
\hline 2 & $\begin{array}{l}\text { Anket formunun geçerliliğinden emin olmak için pilot çalışma } \\
\text { yapılmıştır. }\end{array}$ \\
\hline 3 & Verilerin toplanacağ ${ }_{1}$ hedef şirketler belirlenmiştir. \\
\hline 4 & Veriler toplanmıştır. \\
\hline 5 & $\begin{array}{l}\text { Önleme Maliyetleri ölçeği için tanımlayıcı istatistik analizleri } \\
\text { gerçekleştirilmiştir. }\end{array}$ \\
\hline 6 & $\begin{array}{l}\text { Çalışan Memnuniyeti anket soruları için verilerin normallik dağılımına } \\
\text { bakılmıș ve buna göre Tek-Örnek } t \text {-Testi gerçekleștirilmiştir. }\end{array}$ \\
\hline
\end{tabular}

Çevre ve İş Sağlığı ve Güvenliği Yönetim Sistemlerine Yatırim Yapan Firmalarda Çalışan Memnuniyeti Tutumlarinın İncelenmesi

\subsection{Anketin Tasarımı}

Anket üç kısım olarak tasarlanmıştır. Birinci kısımda katılımcı firmaların demografik yapıları hakkında fikir sahibi olunması, ikinci kısımda önleme maliyetleri konusunda katılımcıların yönelimleri ve üçüncü kısımda ise çalışan memnuniyeti tutumlarının incelenmesi amaçlanmıştır. Ayrıca katılımcılara "Belgelendirme süreci dâhil kaç yıldır İSG yönetim sistemini uyguluyorsunuz?" sorusu da yöneltilmiştir.

\section{Önleme Maliyetleri Ölçeği}

Genel olarak çevre maliyetleri önleme maliyetleri, denetleme (detection) maliyetleri, iç başarısızlık maliyetleri ve dış başarısızlık maliyetleri olmak üzere dört ana grupta toplanmaktadır. Çevre önleme maliyetleri, üretimin bir sonucu olarak ortaya çıkarak çevreye zarar verme ihtimali olan atık ve kirleticilerden sakınmak amacıyla yapılmaktadır (Keitel vd, 2011). Başka bir deyişle, üretim atıklarından çevreyi korumak amacıyla gerçekleştirilen 
Çevre ve İş Sağlığı ve Güvenliği Yönetim Sistemlerine Yatırım Yapan Firmalarda Çalışan Memnuniyeti Tutumlarının İncelenmesi 58 faaliyetlerin maliyetleridir (Kaplan, 2016). Önleme maliyeti kategorisine diş hizmet alımı, personel, araştırma ve geliştirme, temizleme teknolojileri için yapılan ilave masraflar ve diğer çevre yönetimi maliyetleri girmektedir (Betianu, 2007).

İş kazası ve meslek hastalıklarının maliyeti; bunları ödemek için yapılan harcamalar (önleme maliyetleri) ile sorunlar ortaya çıtıktan sonra yapılan her türlü harcamalar ve neden olduğu kayıpların (iş kazası maliyetleri) toplamıdır (Boyar, 2014). Panopoulos (2013) İSG önleme maliyetlerini; İSGYS dokümantasyonu, İSG personeli, toplantılar, etüt çalışmaları, eğitim, KKD, dış hizmetler, güvenlik ekipmanları, yangın güvenliği, sağlı gözetimi, ajan izleme ve diğer olmak üzere sınıflara ayırmıştır.

Bu çalışmada ISO 14001 ve OHSAS 18001 belgeli firmaların önleme maliyetleri algıları Bayram vd. (2016) tarafından geliştirilen ölçek kullanılarak ölçülmüştür. Önleme maliyetleri ölçeğini oluşturan değişkenler Tablo 2.' de verilmektedir.

Tablo 2. Önleme maliyetleri ölçeği değişkenleri

\begin{tabular}{ll}
\hline Değişken & Açıklama \\
\hline ÖNLE_1 & Personel harcamaları \\
ÖNLE_2 & Eğitim harcamaları \\
ÖNLE_3 & Teknolojik Yatırım Harcamaları \\
ÖNLE_4 & Çalışanların Toplu Korunması için yapılan harcamalar \\
ÖNLE_5 & KKD ve diğer Güvenlik Ekipmanlarına yapılan harcamalar \\
ÖNLE_6 & İşaret ve levhaları için yapılan harcamalar \\
ÖNLE_7 & Dış hizmet alımı harcamaları \\
ÖNLE_8 & Yangın ve Acil Durum yönetimi için yapılan harcamalar \\
\hline
\end{tabular}

\section{Çalışan Memnuniyeti Anket Sorulan}

Çalışan memnuniyeti, gözle görülebilmesi zor olduğu kadar tanımlanması da oldukça zor olan bir kavramdır (Çubukel, 2008). Basit olarak, iş memnuniyeti, "İşgörenin işine karşı gösterdiği olumlu ya da olumsuz genel tutum" olarak açıklanabilir (Öğer, 2009). Çalışan memnuniyeti kişinin işine karşı beslediği gözle görünmeyen duygusal bir tepkidir. Beklentilerin karşılanma derecesi ve yapılan iş sonucu elde edilen maddi veya manevi çıkarlar tatminin oluşmasında önemli unsurlardır (Çubukel, 2008).

Öğer (2009) çalışan memnuniyeti seviyesinin; işgören performansı, işgören devir hızı, devamsızlık, işletmeye zarar verici davranışlar ve işgören sağlığ üzerinde etkilerini ortaya koymuştur. Öğer (2009) çalışması esas alınarak, katılımcı firmaların çalışan memnuniyeti algılarını ölçmek için Bayram vd. (2016) tarafından geliştirilen ölçek değişkenleri kullanılmıştır (Tablo 3.). 
Tablo 3. Çalışan memnuniyeti ölçeği değişkenleri

\begin{tabular}{ll}
\hline Değişken & Açıllama \\
\hline MEMN_1 & Çalışanlarımızın performansı arttı \\
MEMN_2 & İşletmemizin işgücü devir hızı azaldı \\
MEMN_3 & Çalışanlarımızın devamsızlığı azaldı \\
MEMN_4 & Çalışanlarımızın işletmeye zarar verici davranışları azaldı \\
MEMN_5 & Çalışanlarımızın fiziksel ve ruhsal sağlık durumları iyileşti \\
\hline
\end{tabular}

Çevre ve İş Sağlığı ve Güvenliği Yönetim Sistemlerine Yatırım

Anketin çalışan memnuniyeti kısmını oluşturan sorularla ilgili olarak katılımcıların geçmiş dönemler ile son üç yıl karşılaştırıldığında bu beş soruya ait şirket düzeyindeki algılarını " $1=$ Kesinlikle katılmıyorum", ..... 5=Kesinlikle katılıyorum" şeklinde 5'li Likert tipi ölçekte belirtmesi istenmiştir.

\subsection{Veri Toplama ve Örnek}

$\mathrm{Bu}$ çalışmada, veri toplama aracı olarak anket çalışması yapılmıştır. Anket sorularının firmaların çevre/ISG'den sorumlu yöneticileri tarafından cevaplanması istenmiştir. Tasarlanan anket formu beşi firma ziyareti esnasında yetkili yöneticilerle yüz yüze görüşerek, yedisi ise telefon ve mail ile iletişim kurularak tekrar gözden geçirilmiş ve bu suretle doldurulan on iki anket sonucundan alınan geri bildirimlerle anket formu nihai hale getirilmiştir. Verilerin toplanması için ÇYS ve İSGYS uygulayan firmalar hedef kitle olarak belirlenmiştir. Firmaların örneğe dahil edilmesinde kararsal örnekleme uygulanmıştır. Yani araştırmanın ana kütlesini oluşturan Türkiye' deki her iki yönetim sistemin birden uygulayan firmaları temsil ettiğine inandı̆̆ımız bu 576 firma yazarların araştırmaları sonucu belirlenmiştir. Toplamda 162 anket firmalar tarafından doldurularak geri gönderilmiştir. Bunlardan her iki yönetim sistemine birden sahip 148 firmanın anket verileri analize tabi tutulmuştur. Böylece anketin geri dönüş oranı \%25.7 olarak gerçekleşmiştir. Tablo 4.'de ankete katılım sağlanan firmaların profili verilmektedir.

Ankete katılım sağlanabilmesi amacıyla firmaların İSG'den sorumlu yönetici pozisyonunda kişilerle (Çevre/ISG yönetim temsilcisi, çevre/İSG yöneticisi, Çevre görevlisi/ISG uzmanı, kalite müdürü vb) bir sunum mektubu ekinde anketi göndererek, önce telefonla temasa geçip sonra mail ortamında anketi göndererek ve sadece mail ortamında yazışarak üç farklı şekilde temasa geçilmiştir. Firmadaki göreviniz sorusuna 60 katılımcı $(\% 40,5)$ çevre/ISGyönetim temsilcisi, 23 katılımcı $(\% 15,5)$ İSG/çevre yöneticisi ve 41 katılımcı İSG uzmanı/çevre görevlisi ve 24 katılımcı diğer (KYS müdürü, İK müdürü, müdür, KYS sorumlusu vb.) cevaplarını vermişlerdir. 
Çevre ve İş Sağlığı ve

Güvenliği

Yönetim

Sistemlerine

Yatırım Yapan

Firmalarda

Çalışan

Memnuniyeti

Tutumlarının İncelenmesi

60

Tablo 4. Ankete katılım sağlanan firmaların profili $(N=148)$.

\begin{tabular}{lrc}
\hline Karakteristikler & Frekans & $\%$ \\
\hline Faaliyet Sektörü & & \\
$\quad$ Imalat & 110 & 74,3 \\
$\quad$ Hizmet & 38 & 25,7 \\
Mülkiyeti & & \\
$\quad$ Özel & 126 & 85,1 \\
$\quad$ Kamu & 22 & 14,9 \\
Firma Büyüklü̈̆̈̈ (Çalışan Sayısı) & & \\
$\quad 0-250$ & 28 & 16,4 \\
$\quad>250$ & 66 & 38,6 \\
İsyeri Tehlike Sınıfı & & \\
$\quad$ Az tehlikeli & 24 & 16,2 \\
$\quad$ Tehlikeli & 67 & 45,3 \\
$\quad$ Çok tehlikeli & 57 & 38,5 \\
Belge süresi & & \\
$0-5$ yıl & 62 & 41,9 \\
$\quad>5$ yıl & 86 & 58,1 \\
\hline
\end{tabular}

\section{Bulgular}

Araştırma bulguları önleme maliyeti ölçeğine ilişkin tanımlayıcı istatistiksel bulgular ve çalışan memnuniyeti soruları ile ilgili algıları olmak üzere iki başlık altında verilecektir.

\section{1. Önleme maliyetlerine ilişkin tanımlayıcı istatistiksel bulgular}

Önleme maliyetleri açısından verilerin tanımlayıcı istatistik analizi sonucunda Tablo 5.'te verilen bulgulara ulaşılmıştır. Personel, eğitim, teknolojik yatırım, çalışanların toplu korunması, kişisel koruyucu donanım (KKD), İSG işaret ve levhaları, dış hizmet ve yangın ve acil durum yönetimi olmak üzere sekiz sorudan oluşan önleme maliyetlerinin tamaminın aritmetik ortalaması " $4=$ Yasal ve Yönetim Sistemi Şartlarını Tam Sağlayacak Kadar Harcama Yapılır" tercihinin de üzerinde gerçekleşmiştir. Ayrıca, katılımcı firmaların en az "ÖNLE_3 İSG teknolojik yatırım harcamaları" ve "ÖNLE_4- Çalışanların toplu korunması harcamaları" için ve en fazla "ÖNLE_5 KKD ve diğer iş güvenliği ekipmanları harcamaları" için harcama yaptıklarını ortaya koymaktadır.

Firmaların karakteristik özelliklerine bağlı olarak katılımcıların önleme maliyetleri değişkenleri ile ilgili algılarını belirlemek için tanımlayıcı istatistik analizleri ayrıca yapılmıştır. Bu kapsamda firmaların faaliyet sektörü (imalat ve hizmet), firma büyüklüğü (çalışan sayısı 0-250 arası ve çalışan sayısı 250' den fazla) ve yönetim sistemlerinin uygulanma süresi (0-5 
yıl arası ve 5 yıldan fazla süredir) karakteristik özelliklerinin ortalamaları karşılaştırılmıştır. Firmalarının karakteristik özellikleri dikkate alındığında, önleme maliyetleri ile ilgili katılımcıların tanımlayıcı istatistik sonuçları Tablo 6.' daki gibi gerçekleşmiştir.

Tablo 5. Önleme maliyeti ölçeğine ilişkin tanımlayıcı istatistiksel bulgular

\begin{tabular}{|c|c|c|c|c|c|c|c|c|c|c|}
\hline \multirow[t]{2}{*}{$\begin{array}{c}\text { Değişken } \\
\text { Adı }\end{array}$} & 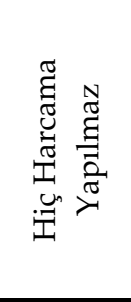 & \multicolumn{2}{|c|}{ 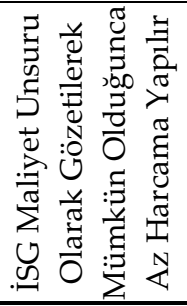 } & \multirow[t]{2}{*}{ 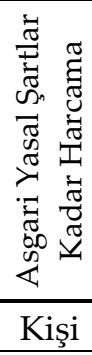 } & \multirow[t]{2}{*}{$\begin{array}{l}\frac{7}{\overrightarrow{2}} \\
\frac{\pi}{2} \\
\end{array}$} & \multicolumn{2}{|c|}{ 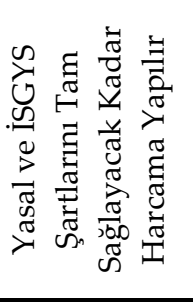 } & \multicolumn{2}{|c|}{ 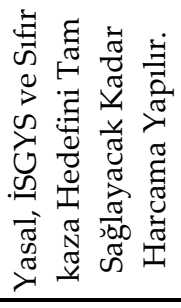 } & \multirow[t]{2}{*}{ Ort. } \\
\hline & Kişi \% & Kişi & $\%$ & & & Kişi & $\%$ & Kişi & $\%$ & \\
\hline ÖNLE_1 & 21,4 & 2 & 1,4 & 18 & 12,2 & 62 & 42,2 & 63 & 42,9 & 4,24 \\
\hline ÖNLE_2 & & 4 & 2,7 & 27 & 18,4 & 55 & 37,4 & 61 & 41,5 & 4,18 \\
\hline ÖNLE_3 & 10,7 & 5 & 3,4 & 33 & 22,4 & 58 & 39,5 & 50 & 34,0 & 4,03 \\
\hline ÖNLE_4 & & 9 & 6,1 & 36 & 24,3 & 44 & 29,7 & 59 & 39,9 & 4,03 \\
\hline ÖNLE_5 & 10,7 & 4 & 2,7 & 13 & 8,8 & 41 & 27,7 & 89 & 60,1 & 4,44 \\
\hline ÖNLE_6 & & 4 & 2,7 & 12 & 8,1 & 52 & 35,1 & 80 & 54,1 & 4,41 \\
\hline ÖNLE_7 & & 4 & 2,7 & 19 & 12,8 & 48 & 32,4 & 77 & 52,0 & 4,34 \\
\hline ÖNLE_8 & & 4 & 2,7 & 24 & 16,2 & 51 & 34,5 & 69 & 46,6 & 4,25 \\
\hline
\end{tabular}

Tablo 6. Katılımcı firmaların karakteristik özelliklerine göre önleme maliyetleri tanımlayıcı istatistik sonuçları

\begin{tabular}{|c|c|c|c|c|c|c|c|}
\hline \multirow{2}{*}{$\begin{array}{l}\text { Değişken } \\
\text { Adı }\end{array}$} & \multicolumn{2}{|c|}{ Faaliyet Sektörü } & \multicolumn{2}{|c|}{$\begin{array}{c}\text { Firma } \\
\text { Büyüklüğü }\end{array}$} & \multicolumn{2}{|c|}{$\begin{array}{l}\text { Belgelendirilme } \\
\text { Süreleri }\end{array}$} & \multirow{2}{*}{$\begin{array}{l}\text { Tümünde } \\
(\mathrm{N}=148)\end{array}$} \\
\hline & $\begin{array}{r}\text { İmalat } \\
(\mathrm{N}=109)\end{array}$ & $\begin{array}{l}\text { Hizmet } \\
(\mathrm{N}=39)\end{array}$ & $\begin{array}{r}0-250 \\
(\mathrm{~N}=66)\end{array}$ & $\begin{array}{l}>250 \\
(\mathrm{~N}=82)\end{array}$ & $\begin{array}{r}0-5 \text { y1l } \\
(\mathrm{N}=62)\end{array}$ & $\begin{array}{c}>5 \text { y1l } \\
(\mathrm{N}=86)\end{array}$ & \\
\hline ÖNLE_1 & 4,26 & 4,18 & 4,17 & 4,29 & 4,18 & 4,28 & 4,24 \\
\hline ÖNLE_2 & 4,17 & 4,21 & 4,08 & 4,26 & 4,05 & 4,27 & 4,18 \\
\hline ÖNLE_3 & 3,99 & 4,13 & 3,88 & 4,15 & 3,85 & 4,15 & 4,03 \\
\hline ÖNLE_4 & 3,97 & 4,21 & 3,89 & 4,15 & 3,94 & 4,10 & 4,03 \\
\hline ÖNLE_5 & 4,43 & 4,46 & 4,38 & 4,49 & 4,29 & 4,55 & 4,44 \\
\hline ÖNLE_6 & 4,39 & 4,44 & 4,30 & 4,49 & 4,29 & 4,49 & 4,41 \\
\hline ÖNLE_7 & 4,33 & 4,33 & 4,29 & 4,37 & 4,21 & 4,42 & 4,34 \\
\hline ÖNLE_8 & 4,25 & 4,26 & 4,15 & 4,33 & 4,23 & 4,27 & 4,25 \\
\hline ORT. & 4,22 & 4,28 & 4,14 & 4,32 & 4,13 & 4,32 & 4,24 \\
\hline
\end{tabular}

Araştırma bulguları önleme maliyetleri konusunda imalat sektörü firmaları ile hizmet sektörü firmalarının çok farklı düşünmediğini ortaya koymaktadır. Ancak elde ettiğimiz bulgulara göre, çalışan sayısı 250'nin
Çevre ve İş Sağlığı ve Güvenliği Yönetim Sistemlerine Yatırım Yapan Firmalarda Çalışan Memnuniyeti Tutumlarının İncelenmesi 61 
Çevre ve İş Sağlığı ve

\section{Güvenliği}

Yönetim

Sistemlerine

Yatırım Yapan

Firmalarda

Çalışan

Memnuniyeti

Tutumlarının İncelenmesi

62 üstündeki firmaların çalışan sayısı 250'nin altındakilerden ve beş yılı aşkın süredir belgili olan firmaların beş yıldan az süredir belgeli olan firmalardan açık ara daha fazla önleme maliyeti yapmaktadır.

Önleme maliyetleri konusunda diğer önemli bir bulgu ise, çalışan sayısı 250'nin altındaki küçük ve orta büyüklükteki firmalar ile beş yıldan daha az süredir yönetim sistemi uygulayan firmaların büyük yatırım harcamalarını içeren teknolojik yatırım ve çalışanların toplu korunmasına yönelik harcamalar konusunda çekimser davranmalarıdır. Zira bu tür yönetim sistemlerini uygulayan firmaların en azından yasal ve yönetim sistemleri şartlarını tam sağlayacak kadar harcama yapmaları gerekir. Bu çalışmaya destek verip, çalışan sayısı 250'nin altında ve beş yıldan daha az süredir yönetim sistemi uygulayan firmaların bu kriteri yerine getirmedikleri bulunmuştur.

Fazla yatırım harcaması gerektirmeyen diğer altı önleme maliyeti değişkeninde (personel, eğitim, KKD, dış hizmet alımı, İşaret ve levhaları için yapılan harcamalar ve yangın-acil durum yönetimi için yapılan harcamalar) ise yasal ve yönetim sistemleri şartlarını tam sağlayacak kadar katılımcı firmalar tarafından harcama yapıldığ

\section{3. Çalışan memnuniyeti tutumları}

Tümünde ve firmaların karakteristik özelliklerine bağlı olarak çalışan memnuniyeti değişkenleri ile ilgili katılımcı algılarının analizi için verilerin normallik dağılımına bakılmış ve buna göre Tek-Örnek t-Testi $(t=3.25)$ kullanılmıştır. Test için eşik değer olarak 3,25 tercih edilmiştir. Likert tipi 5'li ölçek kullanılarak ölçülen değişkenler hususunda katılımcıların tutumlarını belirlemek için test değeri genellikle $3(t=3.0)$ veya 3,5 kullanılmakta olup bu çalışma için ikisinin ortası olan 3,25 tercih edilmiştir. Verilerin tanımlayıcı istatistik analizi sonuçlarından Tablo 7.'te verilen bulgulara ulaşılmıştır.

Ankete katılan firmaların tümü dikkate alındığında; en fazla memnuniyet artışının çalışanların işletmeye zarar verici davranışları azaldı değişkeninde, en az memnuniyet artışının ise işyeri işgücü devir hızı azaldı değişkeninde olduğu bulunmuştur. İmalat ve hizmet sektörleri ayrımı dikkate alındığında, firmalarının benzer memnuniyet artışı sağladıkları, firma büyüklüğü ayrımı dikkate alındığında çalışan sayısı 250'den fazla olan firmaların nispeten az da olsa daha fazla memnuniyet artışı sağladıkları belirtilmiştir. Belgelendirilme Süreleri dikkate alındığında ise 5 yıldan fazla süredir ÇYS ve İSGYS uygulayan firmaların tüm değişkenlerde daha fazla memnuniyet artışı sağladıkları bulunmuştur. 
Tablo 7. Katılımcı firmaların çalışan memnuniyeti ölçeği verilerinin tümünde ve karakteristik özelliklerine göre tanımlayıcı istatistik sonuçları

\begin{tabular}{ccccc}
\hline Değişken Ad1 & $\mathrm{N}$ & Ort. & Std. Sapma & Std. Hata Ort. \\
\hline TÜMÜNDE & & & & \\
MEMN_1 & 147 & 3,73 &, 865 &, 071 \\
MEMN_2 & 146 & 3,21 & 1,097 &, 091 \\
MEMN_3 & 147 & 3,44 & 1,054 &, 087 \\
MEMN_4 & 147 & 3,86 &, 922 &, 076 \\
MEMN_5 & 147 & 3,70 &, 932 &, 077 \\
\multicolumn{2}{c}{ Genel Ort. } & 3,59 & &
\end{tabular}

Faaliyet sektörü ayrımına göre (İmalat, Hizmet)

\begin{tabular}{|c|c|c|c|c|c|c|c|c|}
\hline & İm. & Hiz. & İm. & Hiz. & İm. & Hiz. & İm. & Hiz. \\
\hline MEMN_1 & 109 & 38 & 3,72 & 3,76 & ,851 & ,913 & 081 & 148 \\
\hline MEMN_2 & 108 & 38 & 3,22 & 3,18 & 1,122 & 1,036 & 108 & 168 \\
\hline MEMN_3 & 109 & 38 & 3,39 & 3,55 & 1,063 & 1,032 & 102 & 167 \\
\hline MEMN_4 & 109 & 38 & 3,90 & 3,74 & ,922 & ,921 & ,088 & 149 \\
\hline MEMN_5 & 109 & 38 & 3,70 & 3,71 & ,918 & ,984 & ,088 & 160 \\
\hline Gene & Ort. & & 3,59 & 3,59 & & & & \\
\hline Firma Büyüklüğü & ayrımı & na gi & $(0-250$ & arasi & an, 250 & den $\mathrm{Fa}$ & a çalışa & \\
\hline & $0-250$ & $>250$ & $0-250$ & $>250$ & $0-250$ & $>250$ & $0-250$ & $>250$ \\
\hline MEMN_1 & 65 & 82 & 3,74 & 3,72 & ,834 & 893 & ,103 & ,099 \\
\hline MEMN_2 & 64 & 82 & 3,11 & 3,29 & 1,041 & 1,138 & 130 & 126 \\
\hline MEMN_3 & 65 & 82 & 3,35 & 3,50 & 1,007 & 1,091 & 125 & 121 \\
\hline MEMN_4 & 65 & 82 & 3,88 & 3,84 & ,857 & ,975 & 106 & 108 \\
\hline MEMN_5 & 65 & 82 & 3,60 & 3,78 & 949 & 917 & 118 & 101 \\
\hline Gene & Ort. & & 3,54 & 3,63 & & & & \\
\hline Belgelendirilme Si & releri & $(0-5$ & arası $b$ & elgeli, & ldan $F$ & zzla Sü & dir Bel & geli) \\
\hline & $0-5$ & $>5$ & $0-5$ & $>5$ & $0-5$ & $>5$ & $0-5$ & $>5$ \\
\hline MEMN_1 & 62 & 85 & 3,58 & 3,84 & ,915 & 814 & 116 & 088 \\
\hline MEMN_2 & 61 & 85 & 3,08 & 3,31 & ,971 & 1,175 & 124 & 127 \\
\hline MEMN_3 & 62 & 85 & 3,37 & 3,48 & 1,075 & 1,042 & 137 & 113 \\
\hline MEMN_4 & 62 & 85 & 3,82 & 3,88 & ,878 & ,956 & 112 & 104 \\
\hline MEMN_5 & 62 & 85 & 3,58 & 3,79 & ,933 & ,927 & 118 & 101 \\
\hline Gene & Ort. & & 3,49 & 3,66 & & & & \\
\hline
\end{tabular}

Verilerin normal dağılıma uygun olduğu sonucuna ulaşıldıktan sonra Ankete katılan firmaların çalışan memnuniyeti algılarını ölçmeye yönelik olarak veriler Tek-Örnek t-Testi $(t=3.25)$ analizine tabi tutulmuştur. TekÖrnek t-Testi analiz sonuçları; tümü ve firmaların karakteristik özellikleri dikkate alındığında Tablo 8'deki gibi gerçekleşmiştir.
Çevre ve İş̧ Sağlığı ve Güvenliği Yönetim Sistemlerine Yatırım Yapan Firmalarda Çalışan Memnuniyeti Tutumlarının İncelenmesi 63 
Çevre ve İş Sağlığı ve Güvenliği Yönetim Sistemlerine Yatırım Yapan Firmalarda Çalışan Memnuniyeti Tutumlarının İncelenmesi

64
Tablo 8. Katılımcı firmaların tümünde ve karakteristik özelliklerine göre çalışan memnuniyeti Tek-Örnek Testi sonuçları $(t=3.25)$

\begin{tabular}{|c|c|c|c|c|}
\hline \multirow[b]{2}{*}{ Değişkenler } & \multirow[b]{2}{*}{$t$} & \multicolumn{3}{|c|}{ Anlamlılık } \\
\hline & & $\begin{array}{c}\text { Serbestlik } \\
\text { Derecesi (Sd) }\end{array}$ & $\begin{array}{c}\text { Düzeyi } \\
\text { (2-yönlü) }\end{array}$ & $\begin{array}{c}\text { Ortalama } \\
\text { Fark }\end{array}$ \\
\hline \multicolumn{5}{|l|}{ TÜMÜNDE } \\
\hline MEMN_1 & 6,702 & 146 & ,000 & ,478 \\
\hline MEMN_2 &,- 415 & 145 & (*) 679 &,- 038 \\
\hline MEMN_3 & 2,133 & 146 & ,035 & 185 \\
\hline MEMN_4 & 7,988 & 146 & ,000 & 607 \\
\hline MEMN_5 & 5,863 & 146 & ,000 & ,451 \\
\hline
\end{tabular}

Faaliyet sektörü (İmalat, Hizmet)

İm. Hiz. İm. Hiz. İm. Hiz. İm. Hiz.

$\begin{array}{lllllllll}\text { MEMN_1 } & 5,713 & 3,463 & 108 & 37 & 000 & \text { 001 }\end{array}$

$\begin{array}{lllllllll}\text { MEMN_2 } & -, 257 & -, 391 & 107 & 37 & \left.{ }^{*}\right), 797 & \left.{ }^{*}\right), 698 & -, 028 & -\end{array}$

066

$\begin{array}{lllllllll}\text { MEMN_3 } & 1,419 & 1,808 & 108 & 37 & \left.{ }^{*}\right), 159 & \left.{ }^{*}\right), 079 & , 144 & , 303\end{array}$

$\begin{array}{lllllllll}\text { MEMN_4 } & 7,347 & 3,259 & 108 & 37 & 000 & , 649 & , 002 & , 467\end{array}$

$\begin{array}{lllllllll}\text { MEMN_5 } & 5,087 & 2,885 & 108 & 37 & 000 & , 447\end{array}$

Firma Büyüklüğü (0-250 arası çalışan, 250'den Fazla çalışan)

$\begin{array}{llllllll}0-250 & >250 & 0-250 & >250 & 0-250 & >250 & 0-250 & >250\end{array}$

$\begin{array}{lllllllll}\text { MEMN_1 } & 4,720 & 4,763 & 64 & 81 & , 000 & , 000 & 488\end{array}$

$\begin{array}{lllllllll}\text { MEMN_2 } & -1,081 & , 340 & 63 & 81 & \left(^{*}\right), 284 & \left(^{*}\right), 735 & -, 141 & , 043\end{array}$

$\begin{array}{lllllllll}\text { MEMN_3 } & , 832 & 2,074\end{array}$

$\begin{array}{llllllll}\text { MEMN_4 } & 5,897 & 5,495 & 64 & 81 & , 000 & , 000 & 627\end{array}$

\begin{tabular}{lllllllll} 
MEMN_5 & 2,974 & 5,241 & 64 & 81 &, 004 &, 000 &, 350 &, 530 \\
\hline
\end{tabular}

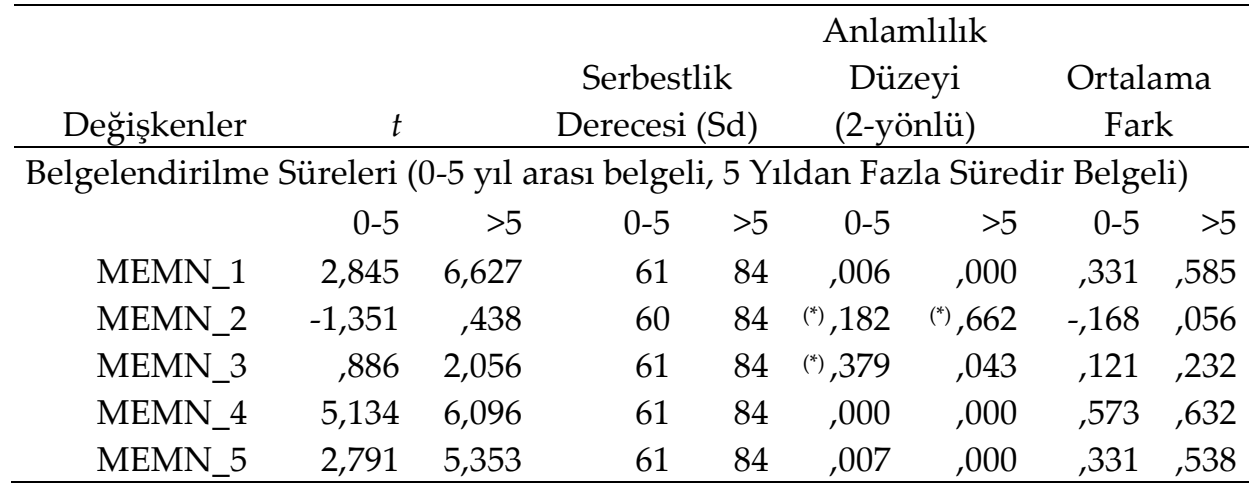

(*) Olumlu tutum belirtilmemiş.

Tablo 8.' de görüleceği üzere, 2 nolu "İşletmemizin işgücü devir hızı azaldı" hariç olmak üzere, 1 nolu "Çalışanlarımızın performansı arttı", 3 nolu "Çalışanlarımızın devamsızlığı azaldı", 4 nolu "Çalışanlarımızın işletmeye zarar verici davranışları azaldı" ve 5 nolu "Çalışanlarımızın fiziksel ve ruhsal sağlık durumları iyileşti" değişkenlerinde firmalar olumlu algı belirtmişlerdir. 
Araştırma bulguları çalışan memnuniyeti konusunda imalat ve hizmet sektörü firmalarının benzer tutuma sahip olduklarını ortaya koymaktadır. Ancak çalışan sayısı 250'nin üstündeki büyük ölçekli firmaların çalışan sayısı 250'nin altındaki küçük ölçekli firmalardan ve beş yılı aşkın süredir belgeli olan firmaların beş yıldan az süredir belgeli olan firmalardan daha fazla olumlu tutum göstermektedir.

İmalat ve hizmet sektörü, çalışan sayısı 250'nin altında ve beş yıldan az süredir belgeli kategorilerinde yer alan firmalar; iki değişkende (işgücü devir hızı ve çalışanların devamsızlığı) olumsuz tutum gösterirken, üç değişkende (çalışanlarının performansı, çalışanların işletmeye zarar verici davranışları ve çalışanların fiziksel ve ruhsal sağlık durumları) olumlu tutum sahibidirler.

Diğer taraftan, çalışan sayısı 250' den fazla olan büyük ölçekli ve beş yıldan fazla süredir yönetim sistemi belgeleri sahip olduklarını beyan eden firmalar işgücü devir hızı değişkeni hariç diğer dört değişkende (çalışanların performansı, çalışanların işletmeye zarar verici davranışları ve çalışanların fiziksel ve ruhsal sağlık durumları) olumlu tutum beyan etmişlerdir.

\section{Sonuçlar}

Bu çalışmada OHSAS 18001 ve ISO 14001 yönetim sistemlerine yatırım yapan firmaların çalışan performansına dolayısıyla karlılık ve verimliğe direk etkisi olan çalışan memnuniyetinde iyileşme sağladıkları ortaya konulmuştur.

İSG önleme maliyetleri açısından bulgular genel olarak değerlendirildiğinde, katılımcı firmaların en az yasal ve İSG yönetim sistemi şartlarını tam sağlayacak kadar harcama yapmakta olduğunu ve hatta sıfır iş kazası hedefine ulaşma konusunda masraftan kaçınmadığını göstermektedir. Böyle olmakla birlikte, sonuçlar işverenlerin büyük yatırım harcaması içeren teknolojik yatırım ve çalışanların toplu korunması harcamalarına göreceli olarak mesafeli durduklarını, buna karşın kolay ve ucuz temin edilen KKD harcamalarına daha istekli yatırım yaptıklarını ortaya koymaktadır. Bir başka deyişle, işverenlerimizin işyeri tehlike ve risklerinin kök nedenlerini ortadan kaldırmaya yönelik büyük yatırım harcamaları yapmak yerine, geçici ve yeterli etkinliğe sahip olmayan palyatif tedbirleri benimsediği bu araştırmanın bir sonucu olarak karşımıza çıkmaktadır.

Çalışan memnuniyetine ilişkin bulgular genel olarak değerlendirildiğinde, genel memnuniyet oranında belirgin bir iyileşme gözlemlenmektedir. $\mathrm{Bu}$

\section{Çevre ve İş Sağlığı ve Güvenliği Yönetim Sistemlerine Yatırım Yapan Firmalarda Çalışan Memnuniyeti Tutumlarının İncelenmesi}


Çevre ve İş Sağlığı ve Güvenliği Yönetim Sistemlerine Yatırım Yapan Firmalarda Çalışan Memnuniyeti Tutumlarının İncelenmesi

66 kapsamda belirlenen beş değişkenin dördünde katılımcılar olumlu algıya sahip olduklarını belirtmişlerdir. Olumlu alg1 gözlemlenmeyen 2 nolu "İşletmemizin işgücü devir hızı azaldı." sorusunun aritmetik ortalaması 3.21 olarak gerçekleşmiştir ki bu değer 3.25 olan test değerine oldukça yakındır. Bu kapsamda en çok iyileşme 4 nolu "Çalışanların işletmeye zarar verici davranışları azaldı." sorusunda olduğu görülmektedir. Bu bulgu katılımcı firmaların İSG kültürü ve bilincini çalışanlarına aşıladığını ima etmektedir. Çalışan memnuniyeti açısından ücret dışı faktörler arasına giren kötü çalışma şartları ve güvensiz çalışma ortamında çalışan işçilerin işi bırakma eğilimlerinin daha yüksek olması gerektiği göz önüne alındığında, katılımcı firmaların sağlıklı ve güvenli işyeri ortamına sahip oldukları öngörülmektedir. Bu bulgu iş güvenliğinin ücrete nazaran iş tatmini üzerinde etkisinin daha yüksek olduğu ampirik olarak ortaya konulan Kanoğlu (2007) çalışması ile tutarlılık göstermektedir.

Ankete katılım sağlanan firmaların imalat/hizmet sektörü karakteristik özelliği dikkate alınarak bulgular göz önüne alındığında; işyeri tehlike ve riskleri daha fazla olan İmalat sektörü firmalarının kaçınılmaz olarak hizmet sektöründekilere nazaran daha fazla önleme maliyeti yaptıklarını ve çalışan memnuniyetinde ise aynı tutuma sahip oldukları görülmektedir. Bu çalışmada mesleki riskleri çok daha az olan hizmet sektöründe faaliyet gösteren firmaların da, kazaları önceden önlemeye dayalı çevre ve İSG yönetimi uygulamalarını önemsediği ve KYS'nin yanı sıra ÇYS ve İSGYS uygulamalarına kaynak tahsis ettiği ortaya konulmaktadır.

Ankete katılım sağlanan firmaların çalışan sayısı karakteristik özelliği dikkate alındığında bulgular; maddi gücü yüksek kurumsallaşmasını tamamlamış büyük ölçekli firmaların yönetim sistemi uygulamalarına daha fazla yatırım yaptıklarını ve bunun kaçınılmaz bir sonucu olarak da çalışan memnuniyetinde daha fazla olumlu tutuma sahip olduklarını ortaya koymaktadır. Bu araştırmaya katkı sağlayan firmalardan maddi gücü yüksek olan büyük ölçekli olanlarının küçük ve orta ölçekli firmalara nazaran iş sağlığı ve güvenliği konusuna daha fazla bütçe tahsis ettiklerini ve nedenle firma ve çalışan performansında büyük etkiye sahip olan çalışan memnuniyetinde daha fazla iyileşme sağladıkları bulunmuştur. Bu araştırmanın önemli bir sonucu kazaların önlenmesi için harcama ve yatırım yapılmasında firma büyüklüğünün dolayısıyla maddi gücün önemli bir kriter olduğudur. Bu sonuçlar Demirbilek ve Pazarlığlu (2006) ve Yorio ve Watcher (2014) çalışmaları ile tutarlılık göstermektedir.

Ankete katılım sağlanan firmaların yönetim sistemlerini uygulama süreleri karakteristik özelliği dikkate alındığında bulgular; beş yılı aşkın süredir yönetimi sistemi uygulayan firmaların yönetim sistemi uygulamalarına 
daha fazla yatırım yaptıklarını ve bunun kaçınılmaz bir sonucu olarak da çalışan memnuniyetinde daha fazla olumlu tutuma sahip olduklarını ortaya koymaktadır. Bu sonuç yönetim sistemi uygulamalarının belli bir olgunluk düzeyine ulaşabilmesi için belirli süre geçmesi gerektiğini ortaya koymaktadır. Bulgular yönetim sistemi uygulamalarında belli bir olgunluk düzeyine sahip olan firmaların diğerlerine nazaran daha fazla önleme yatırımı yaptıklarını ve çalışan memnuniyetinde daha fazla olumlu tutuma sahip olduklarını göstermektedir. Elde ettiğimiz bu sonuç, yönetim sistemlerine yatırımlar yapmak suretiyle pozitif güvenlik kültürüne sahip olan işletmelerin, firma ve çalışan performansına pozitif yönde etki eden çalışan memnuniyetinde artış sağlanabileceğini göstermektedir.

Bundan sonraki bu konudaki araştırmalar NACE kodları esas alınarak belli sektörlere yönelik karşılaştırmalı analizler şeklinde yapılması önerilmektedir.

$\mathrm{Bu}$ araştırmadan elde edilen sonuçların, ülkemiz işverenlerini firma performansına olumlu etkisi olan ÇYS ve İSGYS konusunda mali kaynak ayırma ve yatırım yapma konusunda cesaretlendireceği umulmaktadır.

\section{Kaynakça}

Aytaç, S. (2011) İşyeri kazalarını önlemede güvenlik kültürünün önemi. Türkmetal Dergisi. Oct-Nov: 1-8.

Battaglia, M. Frey, M. and Passetti, E. (2014) Accidents at work and costs analysis: a field study in a large Italian company. Ind Health. 52: 354-366.

Betianu, L. (2007) Environmental Cost Accounting, The Journal of the Faculty of Economics - Economic Science Series, VOL_II: 125-128.

Boyar, C. (2014) 6331 Sayılı İş Sağlığı ve Güvenliği Kanununun Matbaacılık Sektöründe Devlet İşçi İşveren Arasındaki İlişki. Bitirme Projesi, İstanbul: Yeni Yüzyıl Üniversitesi, Sağlık Bilimleri Enstitüsü.

Chan, E.S.W. and Hawkins R. (2010) Attitude towards EMSs in an international hotel: An exploratory case study. International Journal of Hospitality Management, 29:641-651.

Çubukel, R. (2008) Çalışan Memnuniyeti Analizleri, Yüksek Lisans Tezi, İstanbul:İstanbul Üniversitesi, Soysal Bilimler Enstitüsü.

Demirbilek, S. ve Pazarlığlu, M.V. (2006), “Türkiye'de İş kazalarının Oluşumunda Etkili Olan Faktörler: Ampirik Bir Uygulama", Finans Politik\&Ekonomik Yorumlar, 44(509), 81-91.

Gedik, T. (2010) Orman Ürünleri sanayi Sektöründe Çalışan Performansının Belirlenmesi ve Arttırılmasına Yönelik Alan Çalışması (Mobilya ve Levha
Çevre ve İş Sağlığı ve Güvenliği

Yönetim

Sistemlerine

Yatırım

Yapan

Firmalarda

Çalışan

Memnuniyeti

Tutumlarının

İncelenmesi

67 
Çevre ve İş Sağlığı ve

\section{Güvenliği}

Yönetim

Sistemlerine

Yatırım Yapan

Firmalarda

Çalışan

Memnuniyeti

Tutumlarının İncelenmesi

68
Fabrikaları Örneği). Doktora Tezi, Trabzon: Karadeniz Teknik Üniversitesi, Fen Bilimleri Enstitüsü.

Gervais, R. L. Pawlowska, Z. Bojanowski, R. Kouvonen, A. Karanika-Murray, M. Van den Broek, K. ve De Greef, M. (2009) Occupational safety and health and economic performance in SMEs: a review. European Agency for Safety and Health at Work.

Grawitch, M.J. Trares, S. and Kohler, J.M. (2007) Healthy Workplace Practices and Employee Outcomes. Int J Stress Manag., 14(3):275-293.

Gupta, A. ve Upadhyay, D. (2012) Impact of Occupational Health Safety on Employee Satisfaction. Int J Sci Res., Dec, 1(7):118-120.

Huang, Y.T. and Sharyn, R.T. (2014) The moderating effect of cultural congruence on the internal marketing practice and employee satisfaction relationship: An empirical examination of Australian and Taiwanese born tourism employees. Tour Manag., 42:196-206.

Kanoğlu, B. (2007) Çalışan memnuniyeti ve motivasyonuna etki eden unsurlar: İSTAÇ A.Ş. örnek uygulama. Yüksek Lisans Tezi, İstanbul: Marmara Üniversitesi, Sosyal Bilimler Enstitüsü.

Kaplan. (2016) Çevresel maliyet. http://kfknowledgebank.kaplan.co.uk/KFKB/Wiki \%20Pages/Environmental\%20Costing.aspx (09.07.2016).

Kaur, H. (2011) Impact of HR factors on employee attitudes: an empirical analysis of a sample of ISO14001 EMS companies in Malaysia. J Public Administration and Governance,1:1.

Keitel, B. Elizabeth, G. Grisel, P. and Reynier R. (2011)How to Calculate The Environmental Costs? Case Company Grafica Cienfuegos. "Visión de Futuro";Año 8, 15(2), Julio - Diciembre.

Ofluoğlu, G. ve Sarıkaya, G. (2005) OHSAS 18001 İş Sağlığı ve İş Güvenliği Yönetim Sistemi. Kamu-İş̧; C:8, S: 3/2005

Omusulah, I.D. (2013) Percieved Influence of Occupational Health and Safety Practices On Job Satisfaction Among Employees In Chemelil Sugar Company Limited, Master's Thesis, Nairobi (Kenya): The University of Nairobi.

Öğer, C.B. (2009) İnsan kaynaklarında çalışan memnuniyeti ve bir örnek olay. Yüksek Lisans Tezi, İstanbul: Yıldız Technical Üniversitesi. Sosyal Bilimler Enstitüsü.

Panopoulos, G.D. (2003) Economic Aspects of Safety in Greek Conctruction Industry. Aston (UK): Aston University; Doctor of Philosophy.

Pelit, E. ve Öztürk Y. (2010) Otel İşletmeleri İşgörenlerinin İş Doyum Düzeyleri: Sayfiye ve Şehir Otel İşletmeleri İşgörenleri Üzerinde Bir Araştırma. İşletme Araştırmaları Der., 2/1:43-72. 
Quazi, H.A. Khoob, Y.K.K. Tan, C.M. and Wong, P.S. (2001) Motivation for ISO 14000 certification: development of a predictive model. Omega, 29:525-542.

Rikhardsson, P. M. and Impgaard, M. (2004) Corporate cost of occupational accidents: an activity-based analysis. Accid Ana Prev.,36: 173-182.

Tanrıverdi, H. (2006) Sanayi İşletmelerinde Çalışanların İş Tatminsizliği Sorunları Üzerine bir Araştırma. Ekonomik ve Sosyal Araştırmalar Dergisi, 3(2):1-29.

Tarí, J.J. Molina-Azorín, J.F. and Heras, I. (2012) Benefits of the ISO 9001 and ISO 14001 standards: A literature review. Journal of Industrial Engineering and Management, 5(2):296-322.

Torp, S. and Moen, B.E. (2006) The effects of occupational health and safety management on work environment and health: A prospective study. Appl Ergon.,37:775-783.

Bayram, M. Ungan, M.C. and Ardıç, K. (2016). The relationships between OHS prevention costs, safety performance, employee satisfaction and accident costs. T Int J Occ Saf Ergonomics, (JOSE), doi: 10.1080/10803548.2016.1226607

Wachter, J.K. and Yorio, P.L. (2014) A system of safety management practices and worker engagement for reducing and preventing accidents: An empirical and theoretical investigation. Accid Ana Prev., 68:117-130.

Yıldız, Z. (2013) Belediyelerde Çalışan Memnuniyeti: Yalova Belediyesi Örneği. Yüksek Lisans Tezi, Yalova: Yalova Üniversitesi, Sosyal Bilimler Enstitüsü.

Yorio, P. L. and Wachter. J. K. (2014) The impact of human performance focused safety and health management practices on injury and illness rates: Do size and industry matter? Saf Sci., 62: 157-167.

\section{Çevre ve İş Sağlığı ve \\ Güvenliği \\ Yönetim \\ Sistemlerine \\ Yatırım \\ Yapan \\ Firmalarda \\ Çalışan \\ Memnuniyeti \\ Tutumlarının \\ İncelenmesi}

69 